THE JOURNAL GASTRONOMY TOURISM

Volume 1 Nomor 2, Desember 2014, Page 113-124

Available online at:

https://ejournal.upi.edu/index.php/gastur

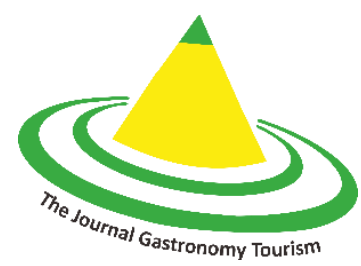

\title{
Strategi Pengembangan Bisnis di Erly's Kue Indramayu
}

\author{
Ibrahim Hisyam, Indriyani Handyastuti, Hurry Mega Insani
}

Universitas Pendidikan Indonesia, Jl. Dr. Setiabudhi No. 229, Bandung 40154, Indonesia

Korespondensi Penulis, E-mail: ibrahimhisyam85@upi.edu

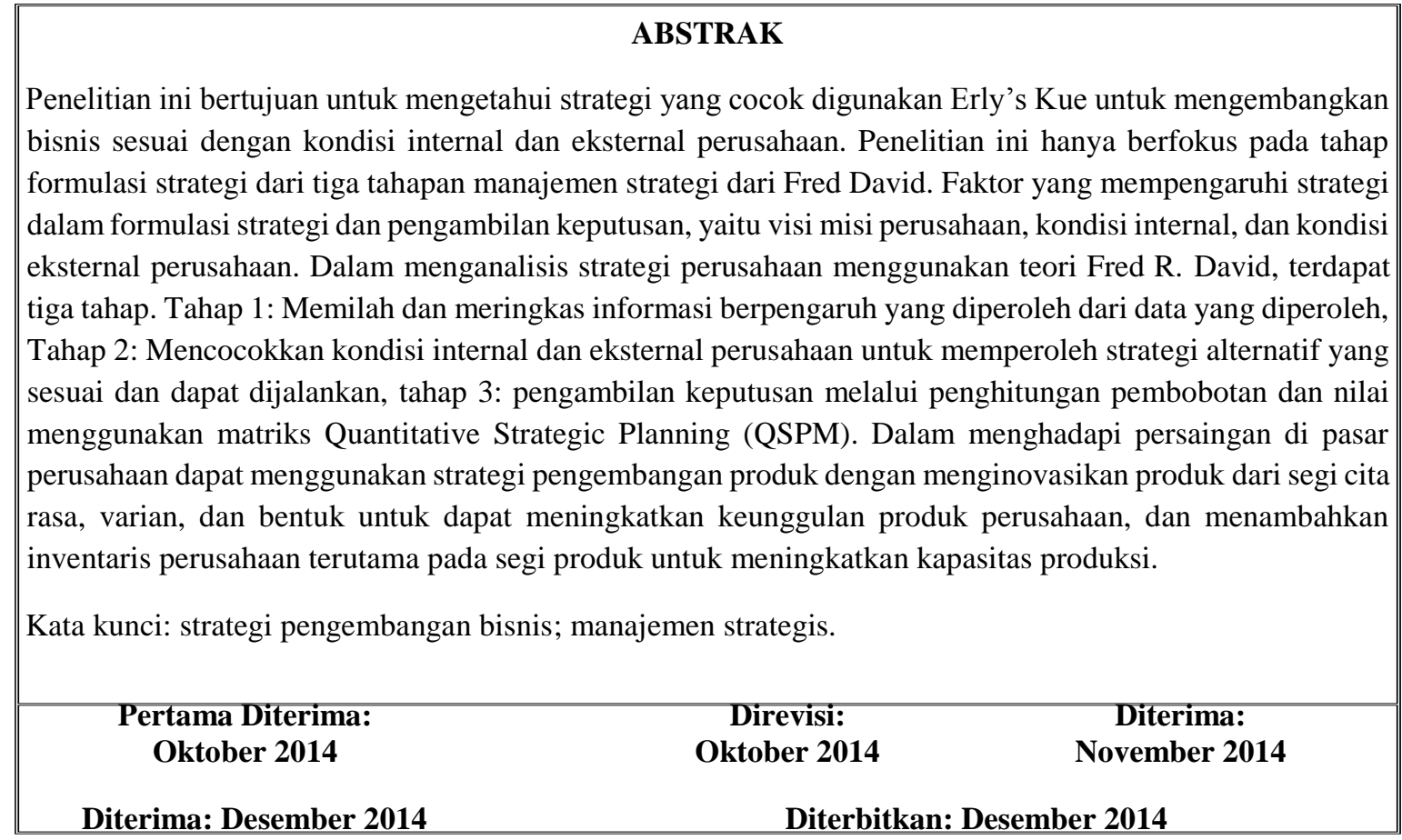




\section{1) Pendahuluan}

UMKM atau Usaha Mikro Kecil Menengah memiliki peran penting dalam pertumbuhan ekonomi daerah bahkan negara. Tenaga kerja yang diserap oleh UMKM membantu mengatasi permasalahan kemiskinan (Hadiwijoyo, 1996). Dalam pariwisata UMKM yang bergerak pada sektor makanan dan minuman (kuliner) dapat digolongkan menjadi golongan usaha pariwisata, usaha makanan dan minuman dalam pariwisata merupakan usaha yang berperan dalam memenuhi kebutuhan wisatawan dengan produk berupa makanan dan minuman.

Kegiatan dalam bisnis yang melibatkan banyak perusahaan membentuk lingkungan persaingan yang ketat, setiap perusahaan berlomba-lomba untuk menjadi yang terbaik agar dapat berada pada puncak rantai persaingan.

Dalam menjalankan suatu usaha diperlukan tindakan-tindakan sistematis agar perusahaan dapat menjaga stabilitas dan mempertahankan kondisi perusahaan (Fred R. David,2017), pengambilan tindakan oleh perusahaan harus selaras dengan tujuan perusahaan agar tindakan yang diambil berfokus pada satu tujuan dan efisien.

Untuk dapat melakukan pengembangan pada bisnis diperlukan beberapa perubahan pada sistem yang telah ada pada perusahaan, pengembangan usaha adalah jumlah seluruh kegiatan yang diorganisir oleh orang-orang yang berkecimpung dalam bidang perniagaan dan industri yang menyediakan barang dan jasa untuk kebutuhan mempertahankan dan memperbaiki standar serta kualitas hidup perusahaan (Glos, Raymond E, et al.,1984)

Strategi pemasaran merupakan serangkaian rencana yang dibuat untuk mengenalkan suatu kegiatan, barang, atau jasa, agar target konsumen yang ingin dituju tercapai. Chandra (Wibowo et al., 2015).

Serangkaian tindakan yang dilakukan perusahaan dalam bisnis untuk mempertahankan dan mengembangkan bisnisnya dapat disebut dengan strategi (Fred R. David, 2017). Keseimbangan dalam bisnis merupakan zona nyaman bagi perusahaan, akan tetapi kondisi seimbang yang dimiliki perusahaan dapat menjadi hal yang negatif bagi perusahaan apabila perusahaan berhenti untuk berkembang dan akan menyebabkan kalah dengan pesaing (Kadariah, 1981).

Strategi dalam bisnis pada umumnya dapat diklasifikasikan ke dalam beberapa bagian seperti strategi dalam hal produk, harga, distribusi, promosi, dan berbagai komponen lainnya. Strategi produk yang dilakukan oleh Erly's Kue yaitu dengan menghasilkan produk-produk yang beragam dari segi jenis dan rasa dan mengedepankan produk yang berkualitas dari segi penampilan dan juga rasa.

Yang menarik dari strategi untuk mengembangkan bisnis adalah, perbedaan strategi yang cocok digunakan untuk perusahaan dalam mengembangkan bisnisnya dapat berbeda meskipun terdapat pada pasar dan industri yang sama karena faktor-faktor yang dimiliki akan berbeda pada tiap perusahaan. Perbedaan strategi yang cocok dengan perusahaan akan didasari pada visi misi perusahaan, kondisi internal, dan kondisi eksternal perusahaan.

Penulis menilai bahwa Erly's kue sudah menjalankan berbagai taktik dalam menjalankan usahanya, akan tetapi dalam menjalankan bisnis, taktik yang berdiri sendiri tidak cukup maka dalam hal ini dibutuhkan pengintegrasian antara satu taktik dengan taktik yang lainnya agar menjadi strategi. 


\section{2) Studi Literatur}

\subsection{Bisnis Pariwisata}

Hadiwijoyo, (1996) menjelaskan bahwa pariwisata adalah jenis industri baru yang dapat mempercepat pertumbuhan ekonomi dan menyediakan lapangan kerja, meningkatkan pendapatan, standar hidup, dan mendorong sektor produksi lainnya. Dalam Pasal 27 Ayat 3 UU Nomor 11 Tahun 2008 tentang Kepariwisataan, usaha pariwisata merupakan bisnis yang menghasilkan produk dan jasa yang dibutuhkan dalam kegiatan pariwisata, bisnis pariwisata selalu berkaitan dengan pemenuhan kebutuhan-kebutuhan pelaku kegiatan pariwisata.

Berdasarkan bidangnya bisnis pariwisata terbagi menjadi beberapa bagian usaha: (1)Daya tarik wisata (2)Kawasan pariwisata (3)Jasa Transportasi (4)Jasa perjalanan wisata (5)Makanan dan minuman (6)Penyediaan akomodasi (7)Penyelenggara kegiatan hiburan (8)Jasa informasi (9)Jasa konsultasi pariwisata (10)Jasa pramuwisata (11)Wisata tirta (Spa).

\subsection{Usaha Makanan dan Minuman}

Usaha jasa makanan dan minuman adalah usaha penyediaan makanan dan minuman yang dilengkapi dengan peralatan dan perlengkapan untuk proses pembuatan, penyimpanan dan/atau penyajiannya (Deputi Bidang Pengembangan Destinasi dan Industri Pariwisata Kementerian Pariwisata Republik Indonesia, 2016). Usaha makanan dan minuman merupakan satu bidang dari usaha pariwisata, pada bidang usaha makanan dan minuman terdapat sub bidang yang terdiri dari jenis usaha dari bisnis makanan dan minuman di dalamnya. Erly's kue termasuk ke dalam perusahaan yang bergerak pada bidang usaha jasa makanan dan minuman.

\subsection{Strategi}

Strategi merupakan tindakan yang harus diambil untuk memenuhi tujuan jangka panjang, rentang waktu ideal dari sebuah strategi berkisar antara 3 hingga 5 tahun. Tanpa tujuan jangka panjang yang jelas perusahaan akan berjalan tanpa arah dan tujuan, oleh karena itu menetapkan tujuan perusahaan merupakan hal yang krusial (Fred, David,2017)

Dalam menentukan tujuan, perusahaan harus memenuhi berbagai karakteristik, antara lain kuantitatif, terukur, realistis, dapat dimengerti, menantang, hierarkis, dapat diperoleh, dan selaras dengan setiap bagian dalam perusahaan. Membuat tujuan perusahaan dengan jelas akan memberikan banyak keuntungan bagi perusahaan

Proses manajemen strategis (strategic management process) terdiri dari tiga tahap: formulasi/ perumusan strategi, implementasi strategi, dan evaluasi strategi seperti pada model komprehensif proses manajemen strategi.

1) Formulasi Strategi

Dalam proses ini, bentuk buatan dari strategis yang komprehensif berupa arah dan ukuran. Proses ini adalah dasar dari konstruksi strategi, dalam formulasi strategi terbagi menjadi 3 tahapan, analisis lingkungan internal, analisis lingkungan eksternal, analisis visi dan misi perusahaan

2) Implementasi strategi

Merupakan proses implementasi strategi yang melibatkan semua sumber Kekuatan yang dimiliki organisasi. Sebagai pemahaman tentang konsep dasar manajemen strategis.

\section{3) Evaluasi Strategi}

Merupakan pengkajian ulang dan penyesuaian pada strategi yang sudah diimplementasikan pada perusahaan, keadaan pada lingkungan eksternal 
sering kali berubah sehingga dibutuhkan penyesuaian pada proses manajemen strategi ini.

\subsection{Jenis Strategi}

Strategi secara garis besar terbagi menjadi 4 kelompok strategi dengan 14 turunannya (Fred R. David, 2017):

\section{a) Integration Strategies}

Strategi ini memfokuskan perusahaan untuk melakukan pengawasan yang lebih terhadap distributor, pemasok, dan pesaing dengan cara merger, mengambil alih, ataupun menciptakan perusahaan sendiri. Integration strategies dibagi menjadi tiga jenis strategi, yaitu forward, backward, dan horizontal.

\section{b) Intensive Strategies}

Kelompok strategi ini disebut sebagai intensive strategies, karena mensyaratkan berbagai upaya yang intensif untuk meningkatkan posisi kompetitif perusahaan dengan produk yang ada. Kelompok strategi ini meliputi tiga strategi, yaitu Market Penetration, Market development, dan Product Development.

\section{c) Diversification Strategies}

Dari waktu ke waktu semakin sedikit perusahaan yang melakukan diversifikasi usaha, justru karena kompleksitas persoalan yang dimunculkan oleh strategi ini. Suatu kelompok usaha yang bergerak pada sektor yang beragam tentunya sangat sulit untuk dikelola. Pada dekade 1960-an dan 1970-an, strategi diversifikasi menjadi populer karena setiap perusahaan berusaha semaksimal mungkin agar tidak tergantung hanya pada satu jenis usaha saja. Terdapat tiga jenis strategi, yaitu Coencentric Diversification, Horizontal Diversification, dan Conglomerate Diversification.s

\section{d) Defensive Strategies}

Pada prinsipnya, strategi defensif ditujukan untuk mempertahankan eksistensi perusahaan dari semakin ketatnya persaingan bisnis dan berbagai ketidakpastian eksternal yang sulit (terkadang tidak mungkin) dikontrol dan diprediksi. Strategi defensif sering pula dikenal sebagai survival strategy, yang cenderung terjadi dalam suasana krisis ekonomi. Pada strategi bertahan terdapat lima jenis strategi, yaitu Joint Venture, Retrenchment, Diverstiture, Liquidation, dan Combination.

\subsection{Variabel Perumusan Manajemen Strategis}

Edward Deming dalam Fred R. David, hlm.34 (2011) pernah berkata, "In God we trust, all others bring data" Manajemen strategis dapat digambarkan sebagai pendekatan yang obyektif, logis, dan sistematis untuk membuat keputusan besar dalam sebuah perusahaan. Pendapat ini menunjukkan pentingnya sebuah informasi baik kualitatif maupun kuantitatif dalam tahapan membuat strategi untuk mengambil keputusan yang efektif dalam perjalanan bisnis yang bersifat dinamis. Variabel yang digunakan untuk menilai perusahaan dapat dikategorikan ke dalam tiga kelompok faktor, meliputi:

1) Visi \& Misi

Visi yang dimiliki perusahaan setidaknya dapat menunjukkan akan menjadi apa perusahaan di kemudian hari, visi dapat dikatakan baik apabila visi memberikan dasar misi yang jelas kepada perusahaan sekurang-kurangnya visi perusahaan harus menggambarkan jenis perusahaan tersebut.

Misi perusahaan adalah dasar untuk prioritas, strategi, rencana, dan tugas kerja perusahaan Hal ini merupakan langkah awal untuk desain pekerjaan dan struktur organisasi.

Menurut Vern McGinnis, pernyataan misi seharusnya (1) mendefinisikan apa organisasi itu dan apa yang dicita-citakan organisasi, (2) cukup terbatas untuk mengecualikan beberapa usaha dan cukup luas untuk memungkinkan pertumbuhan kreatif, (3) 
membedakan organisasi tertentu dari yang lain, (4) berfungsi sebagai kerangka kerja untuk mengevaluasi kegiatan saat ini dan prospektif, dan (5) dinyatakan dalam istilah yang cukup jelas untuk dipahami secara luas di seluruh organisasi.

2) Faktor internal

Faktor internal merupakan variabel yang dapat mengidentifikasi kekuatan dan kelemahan dalam segi operasional yang berupa fungsi manajemen, Pemasaran, produksi, dan sumber daya (Strength and Weakness) di dalam suatu perusahaan, meliputi:

1) Manajemen

2) Sumber daya manusia

3) Pemasaran dan distribusi

4) Keuangan

5) Produksi / operasi

6) Penelitian dan pengembangan

7) Sistem informasi manajemen.

\section{3) Faktor eksternal}

Faktor eksternal merupakan faktor yang terdapat di luar perusahaan yang menunjukkan peluang dan ancaman (Opportunities and Threats) terhadap perusahaan. Dalam faktor eksternal, teori Porter Five Forces membantu memahami kondisi eksternal perusahaan dengan menggunakan pendekatan persaingan. Dalam Porter Five Forces terdapat 5 faktor, yaitu:

1) Threat of new entrance

2) Bargaining power of buyers

3) Bargaining power of suppliers

4) Threat of substitute product

5) Competitive rivalry.

\subsection{Hipotesis}

Dalam suatu penelitian hipotesis merupakan asumsi yang dianggap sebagai jawaban sementara untuk permasalahan yang ada, menurut Sugiyono
(2014) hipotesis dapat dikatakan sebagai jawaban sementara untuk masalah penelitian. Dikatakan bersifat sementara karena jawabannya hanya berdasarkan teori yang relevan, bukan fakta empiris yang diperoleh dari pengumpulan data. Berdasarkan kerangka ideologis di atas, penulis mengajukan hipotesis sebagai berikut dalam melakukan penelitian ini:

1) Visi misi, lingkungan eksternal, dan lingkungan internal memiliki peran besar dalam proses pembentukan strategi.

2) Analisis SWOT terbukti dapat mengidentifikasi masalah dan menentukan taktik yang strategis dalam manajemen strategis.

3) Taktik strategis berperan sebagai pendukung manajemen strategis.

\subsection{Objek dan Subjek Penelitian}

Objek penelitian menggambarkan apa atau siapa objek penelitian yang dilakukan. Objek penelitian dalam penelitian ini adalah aspek - aspek dalam strategi pengembangan bisnis yaitu, manajemen produksi, pemasaran, keuangan.

Subjek penelitian dalam penelitian ini adalah Erly's Kue selaku perusahaan yang bersedia untuk diteliti. Alasan penulis untuk memilih perusahaan ini sebagai subjek penelitian dikarenakan perusahaan ini sudah lama berdiri sehingga penulis menganggap bahwa perusahaan ini memiliki stabilitas yang baik.

\subsection{Teknik Pengumpulan Data \\ Data yang digunakan dalam penelitian ini antara} lain adalah data sekunder. Data sekunder adalah data yang tidak diperoleh langsung dari sumbernya, terdapat pada penelitian, literatur, dan berbagai sumber lainnya. Pada penelitian ini data sekunder diperoleh dari wawancara dengan pemilik usaha dan laporan keuangan perusahaan di dalamnya terdapat data mengenai pendapatan dan pengeluaran tiap 
bulannya pada periode tahun 2019. Data sekunder yang diambil oleh peneliti dalam penelitian ini antara lain:
1) Laporan keuangan perusahaan
2) Wawancara
3) Observasi

2.9 Metode dan Sumber Data

Penelitian ini menggunakan jenis metode deskriptif dan verifikasi dengan pendekatan kualitatif. Penelitian menggunakan metode deskriptif dengan maksud untuk mendapatkan data awal untuk melihat kondisi perusahaan dan menilai strategi bisnis yang efektif digunakan pada perusahaan Erly’s kue.

Dalam merumuskan strategi perusahaan dibutuhkan formulasi strategi untuk mengidentifikasi strategi yang sesuai dengan kondisi perusahaan. Langkah - langkah yang dilakukan dalam melakukan formulasi strategi perusahaan Fred R. David (2017), yaitu:

1) Analisis Visi dan Misi.

Visi: Menjadi pionir dalam memproduksi kudapan tradisional dan modern yang memiliki harga terjangkau dengan memperdayakan sumber daya manusia sekitar.

Misi:

1) Memberikan harga yang murah tanpa mengesampingkan cita rasa dan kualitas produk.

2) Mengoptimalkan proses produksi perusahaan dan sumber daya manusia untuk memperoleh keuntungan yang maksimal.

3) Mengikuti tren dan perkembangan pada pasar makanan untuk menciptakan kudapan dan perusahaan yang dapat bertahan di puncak pasar.

4) Memperdayakan warga daerah sekitar Indramayu sebagai sumber daya manusia perusahaan.2)

Analisis Faktor Internal.
Melihat dan mengidentifikasi kekuatan dan kelemahan dari kondisi internal perusahaan menggunakan matriks IFE berdasarkan faktor-faktor fungsi manajemen.

3) Analisis Faktor Eksternal.

Melihat dan mengidentifikasi peluang dan ancaman dari kondisi eksternal perusahaan seperti kondisi pasar, persaingan, dll. Menggunakan matriks EFE berdasarkan teori Porter Five Forces.

4) Analisis SWOT

Mengidentifikasi strategi yang dapat dipilih berdasarkan faktor internal dan faktor eksternal yang sudah dianalisis menggunakan matriks IFE dan matriks EFE.

5) Analisis Matriks IE

Mengidentifikasi strategi alternatif yang cocok digunakan perusahaan berdasarkan faktor internal dan faktor eksternal perusahaan.

6) Analisis Matriks QSPM

Mengidentifikasi strategi alternatif yang paling sesuai dengan kondisi perusahaan berdasarkan hasil dari matriks IE menggunakan sistem pembobotan dan rating.

\section{3) Hasil dan Pembahasan}

3.1 Visi dan Misi

Perusahaan belum memiliki visi dan misi perusahaan.

\subsection{Aspek Internal}

Dari data yang didapatkan diperoleh beberapa aspek internal yang memiliki pengaruh besar terhadap perusahaan

1) Cita rasa dan kualitas produk yang baik 0,80

Menurut hasil wawancara penulis dengan pemilik perusahaan, perusahaan menggunakan bahan baku berkualitas sebagai bahan membuat produknya, hal ini membuat perusahaan memiliki cita rasa dan kualitas produk yang baik. Hal ini didukung dengan 
sedikitnya keluhan mengenai produk yang diterima oleh perusahaan

2) Produk yang beragam 0,51

Perusahaan memproduksi makanan daerah sebagai produk utamanya, makanan yang disediakan terdiri dari 40 jenis kue tradisional, 15 jenis makanan tradisional yang sudah dikembangkan, dan 21 jenis makanan modern, total produk yang ditawarkan perusahaan berjumlah 71 item makanan ringan yang terbagi menjadi 4 jenis yaitu makanan basah, makanan kering, pastry, dan bolu(cake). Pelanggan memiliki selera yang berbeda banyaknya jenis makanan membuat pelanggan memiliki banyak pilihan dan memperluas cakupan pasar.

3) Kapasitas produksi 0,45

Keuntungan yang didapatkan perusahaan kebanyakan diperoleh melalui pemesanan dengan kuantitas yang banyak. Setiap harinya perusahaan memproduksi 8500 pes untuk penjualan harian, perusahaan mampu melayani pemesanan dengan kuantitas besar sebesar 3000 hingga 5000 kotak, dalam 1 kotak terdapat 3 hingga 4 jenis makanan. Dapat dikatakan bahwa kapasitas produksi perusahaan adalah 16000 hingga 28000pcs.

4) Posisi pasar yang kuat 0,33

Erly's kue merupakan perusahaan pelopor dari bisnis usaha makanan tradisional, hal ini membuat nama perusahaan dikenal luas di daerah Indramayu. Dengan nama yang sudah dikenal luas dan kualitas produk yang baik perusahaan memiliki citra yang baik di pasar.

5) Net profit 0,06

Dalam studi dokumentasi pada data pendapatan tahun 2019 yang diberikan pemilik perusahaan, Erly’s kue mencatat gross profit mencapai angka Rp. 4,021,137,900 dan pendapatan bersih senilai Rp. 294,710,800 dengan data itu didapatkan bahwa net profit rata-rata tahunan pada tahun 2019 mencapai angka $7 \%$.

6) Biaya produksi tinggi 0,39

Penggunaan bahan baku berkualitas tinggi untuk menghasilkan produk yang berkualitas membuat biaya produksi dari produk yang menjadi tinggi. Dengan tingginya biaya produksi akan membuat persentase keuntungan atas suatu produk menjadi rendah, hal ini membuat perusahaan harus mematok harga yang tinggi atas suatu produk untuk meningkatkan persentase keuntungan.

7) Teknologi terbatas 0,10

Teknik produksi perusahaan didominasi oleh kecakapan tangan tenaga kerjanya, produk tradisional sulit diproduksi menggunakan mesin meskipun ada mesin yang dapat membuatnya mesin tersebut akan berharga sangat mahal.

8) Kualitas pelayanan 0,27

Tenaga pelayanan pada beberapa outlet yang dimiliki perusahaan menunjukkan perilaku yang kurang ramah, fenomena ini ditemukan saat peneliti melakukan observasi ke outlet yang dimiliki perusahaan.

9) Kurangnya kegiatan pemasaran 0,28

Perusahaan hanya berfokus pada pemasaran pada konsumen yang sudah sering melakukan transaksi, hal ini membuat nama perusahaan tidak meluas dan cakupan pasar dari perusahaan cenderung stagnan dan tidak berkembang

\begin{tabular}{|l|l|l|l|}
\hline \multicolumn{1}{|c|}{ Faktor } & Bobot & Rating & Nilai \\
\hline Strength & & \\
\hline
\end{tabular}




\begin{tabular}{|c|c|c|c|c|}
\hline & $\begin{array}{l}\text { Memiliki kualitas dan cita rasa } \\
\text { produk yang baik }\end{array}$ & 0,20 & 4 & 0,80 \\
\hline 2 . & Produk yang beragam & 0,17 & 3 & 0,51 \\
\hline 3. & Kapasitas produksi & 0,15 & 3 & 0,45 \\
\hline 4. & Posisi pasar yang kuat & 0,11 & 3 & 0,33 \\
\hline 5 . & $\begin{array}{l}\text { Net profit tahun } 2019 \text { mencapai } \\
7 \%\end{array}$ & 0,03 & 2 & 0,06 \\
\hline \multicolumn{5}{|c|}{ Weakness } \\
\hline 1. & Biaya produksi tinggi & 0,13 & 3 & 0,39 \\
\hline & $\begin{array}{l}\text { Teknologi dalam produksi } \\
\text { terbatas }\end{array}$ & 0,05 & 2 & 0,10 \\
\hline 3. & $\begin{array}{l}\text { Kualitas pelayanan yang kurang } \\
\text { baik }\end{array}$ & 0,09 & 3 & 0,27 \\
\hline 4. & $\begin{array}{l}\text { Kegiatan pemasaran masih } \\
\text { rendah }\end{array}$ & 0,07 & 4 & 0,28 \\
\hline & Total & 1 & & 3.19 \\
\hline
\end{tabular}

\subsection{Aspek Eksternal}

1) Pemesanan skala besar, 0,60

Setiap acara yang melibatkan orang banyak akan menimbulkan kebutuhan atas makanan dan akan terjadi permintaan yang banyak pula. Erly's kue sudah dikenal baik dan dipercaya untuk mengisi kebutuhan konsumsi banyak orang di dalam acara, tidak jarang permintaan konsumsi datang dari perusahaan swasta bahkan instansi-instansi pemerintahan setempat

2) Tingkat konsumsi 0,44

Kenaikan upah minimum di wilayah operasional perusahaan akan berdampak langsung pada tingkat konsumsi rumah tangga dalam masyarakat. Meningkatnya hasrat konsumsi akan meningkatkan peluang untuk perusahaan menjual lebih banyak.

\section{3) Supplier 0,14}

Perusahaan menandatangani kontrak dengan beberapa pelaku bisnis lainnya sebagai supplier bahan baku. Dengan perjanjian kedua belah pihak yang adil maka akan menurunkan kemungkinan akan terjadinya kesewenang-wenangan satu pihak tertentu.

4) Terpercaya 0,51
Erly's kue dikenal memiliki kualitas produk dan cita rasa yang baik dengan harga yang tidak terlalu tinggi. Perusahaan telah berdiri sejak tahun 2007 telah mendapat kepercayaan di masyarakat.

5) Perkembangan teknologi (bisnis) 0,27

Perkembangan internet dan teknologi memiliki dampak yang besar bagi bisnis, internet dan teknologi dapat membuat berbagai macam hal lebih efisien. Seperti dalam pemasaran, dengan perkembangan internet dan teknologi, pemasaran dapat dilakukan dengan biaya yang lebih kecil dan tingkat keefektifan yang lebih tinggi.

6) Globalisasi 0,09

Makanan tradisional dapat diklasifikasikan ke dalam salah satu kebudayaan Indonesia. Semakin meluasnya globalisasi membuat banyak kebudayaan dari luar masuk ke Indonesia, termasuk makanan di dalamnya. Globalisasi membuat perkembangan di dunia makanan semakin cepat, tidak aneh apabila makanan tradisional akan tergeser keberadaannya.

7) Pendatang baru 0,10

Bisnis makanan merupakan salah satu lini usaha bisnis yang termasuk mudah untuk memasukinya, bahan baku yang mudah didapat, modal awal yang diperlukan tidak terlalu besar, dan cepatnya arus perputaran kas yang terjadi. Mudahnya memasuki industri membuat potensi datangnya pesaing semakin meningkat.

8) UMK daerah rendah 0,39

Berdasarkan Surat Keputusan Gubernur Jawa Barat Nomor 561/Kep.774-Yanbangsos/2020 tentang Upah Minimum Kabupaten/Kota di Daerah Provinsi Jawa Barat, UMK kota Indramayu pada tahun 2021 ditetapkan sebesar Rp. 2,373,073. Meski mengalami kenaikan pada tahun sebelumnya, UMK kabupaten Indramayu masih tergolong rendah dibandingkan dengan daerah Jawa Barat lainnya. Rendahnya nilai 
UMK secara langsung akan mempengaruhi daya beli masyarakat, masyarakat yang memiliki pendapatan rendah akan cenderung membeli produk dengan harga yang relatif lebih murah.

9) Perubahan harga bahan baku 0,80

Tidak jarang harga bahan baku melonjak pada saat-saat tertentu seperti hari raya, kenaikan bahan baku melonjak dikarenakan kapasitas produksi tidak dapat mencukupi jumlah permintaan sehingga terjadi kelangkaan yang membuat harga melambung tinggi.

\begin{tabular}{|l|c|c|c|}
\hline \multicolumn{1}{|c|}{ Faktor } & Bobot & Rating & Nilai \\
\hline Opportunity & & & \\
\hline 1. Banyak pemesanan skala besar & 0,15 & 4 & 0,60 \\
untuk acara & 0,11 & 4 & 0,44 \\
2. Perkembangan tingkat konsumsi \\
3. Memiliki banyak supplier & 0,07 & 2 & 0,14 \\
4. Banyak instansi yang sudah & 0,17 & 3 & 0,51 \\
percaya terhadap perusahaan & & & \\
6. Perkembangan teknologi dalam & 0,09 & 2 & 0,27 \\
bisnis & & & \\
\hline Threat & 0,03 & 3 & 0,09 \\
\hline 1. Globalisasi (makanan luar & & & \\
negeri) & 0,05 & 2 & 0,10 \\
2. Mudahnya masuk ke Industri & 0,13 & 3 & 0,39 \\
3. UMK yang rendah (daya beli) & 0,20 & 4 & 0,80 \\
4. Perubahan seketika harga pasar \\
bahan baku
\end{tabular}

\subsection{Analisis SWOT}

\section{Strategi SO}

1) Meningkatkan dan mempertahankan kepercayaan konsumen dengan kualitas produk yang dimiliki

2) Meningkatkan pendapatan perusahaan dengan berfokus pada pemesanan skala besar.

\section{Strategi WO}

1) Menekan harga bahan baku untuk mengurangi biaya produksi yang tinggi
2) Menggunakan berbagai marketplace untuk meningkatkan pemasaran

3) Menekan harga bahan baku dengan melakukan penawaran ke pemasok.

4) Perubahan harga bahan baku

\section{Strategi ST}

1) Melakukan inovasi produk untuk bersaing dengan makanan luar

2) Menjual citra merek yang baik agar konsumen tidak pindah ke pesaing

3) Melakukan kontrak tertulis dengan berbagai perusahaan untuk menjadi pemasok tetap

\section{Strategi WT}

1) Meningkatkan promosi dan penawaran menarik untuk menahan konsumen

2) Menambah alat produksi guna mengurangi beban gaji pegawai

3) Meningkatkan kualitas pelayanan agar produk perusahaan dapat bersaing dengan produk lainnya.

\begin{tabular}{|c|c|c|}
\hline Faktor Internal & $\begin{array}{l}\text { Kekuatan - } \mathbf{S} \\
\text { 1. Kualitas produk } \\
\text { 2. Produk beragam } \\
\text { 3. Kapasitas produksi } \\
\text { 4. Posisi pasar yang } \\
\text { kuat } \\
\text { 5. Net profit baik }\end{array}$ & $\begin{array}{l}\text { Kelemahan - W } \\
\text { 1. biaya produksi } \\
\text { tinggi } \\
\text { 2. teknologi } \\
\text { produksi } \\
\text { terbatas } \\
\text { 3. pelayanan } \\
\text { kurang } \\
\text { 4. pemasaran } \\
\text { belum } \\
\text { maksimal }\end{array}$ \\
\hline Peluang - O & Strategi SO & Strategi WO \\
\hline $\begin{array}{l}\text { 1. Pemesanan } \\
\text { skala besar }\end{array}$ & $\begin{array}{l}\text { 1. Meningkatkan } \\
\text { dan }\end{array}$ & $\begin{array}{l}\text { 1. Menekan harga } \\
\text { bahan baku }\end{array}$ \\
\hline $\begin{array}{l}\text { 2. Perkembangan } \\
\text { tingkat }\end{array}$ & $\begin{array}{l}\text { mempertahankan } \\
\text { kepercayaan }\end{array}$ & $\begin{array}{l}\text { untuk } \\
\text { mengurangi }\end{array}$ \\
\hline konsumsi & & biaya produksi \\
\hline 3. Supplier & kualitas produk & yang tinggi \\
\hline $\begin{array}{l}\text { Diversity } \\
\text { 4. Kepercayaan }\end{array}$ & yang dimiliki & $\begin{array}{l}\text { 2. Menggunakan } \\
\text { berbagai }\end{array}$ \\
\hline
\end{tabular}




\begin{tabular}{|c|c|c|}
\hline $\begin{array}{l}\text { 5. Perkembangan } \\
\text { model bisnis }\end{array}$ & $\begin{array}{l}\text { 2. Meningkatkan } \\
\text { pendapatan } \\
\text { perusahaan } \\
\text { dengan berfokus } \\
\text { pada pemesanan } \\
\text { skala besar. }\end{array}$ & $\begin{array}{l}\text { marketplace } \\
\text { untuk } \\
\text { meningkatkan } \\
\text { pemasaran } \\
\text { 3. Menekan harga } \\
\text { bahan baku } \\
\text { dengan } \\
\text { melakukan } \\
\text { penawaran ke } \\
\text { pemasok. }\end{array}$ \\
\hline $\begin{array}{l}\text { Ancaman - T } \\
\text { 1. Globalisasi } \\
\text { 2. Pesaing baru } \\
\text { 3. Daya beli } \\
\text { rendah } \\
\text { 4. Perubahan } \\
\text { harga bahan } \\
\text { baku }\end{array}$ & $\begin{array}{l}\text { Strategi ST } \\
\text { 1. Melakukan inovasi } \\
\text { produk untuk } \\
\text { bersaing dengan } \\
\text { makanan luar } \\
\text { 2. Menjual citra } \\
\text { merek yang baik } \\
\text { agar konsumen } \\
\text { tidak pindah ke } \\
\text { pesaing } \\
\text { 3. Melakukan } \\
\text { kontrak tertulis } \\
\text { dengan berbagai } \\
\text { perusahaan untuk } \\
\text { menjadi pemasok } \\
\text { tetap } \\
\text { 4. }\end{array}$ & $\begin{array}{l}\text { Strategi WT } \\
\text { 1. Meningkatkan } \\
\text { promosi dan } \\
\text { penawaran } \\
\text { menarik untuk } \\
\text { menahan } \\
\text { konsumen } \\
\text { 2. Menambah alat } \\
\text { produksi guna } \\
\text { mengurangi } \\
\text { beban gaji } \\
\text { pegawai } \\
\text { 3. Meningkatkan } \\
\text { kualitas } \\
\text { pelayanan agar } \\
\text { produk } \\
\text { perusahaan } \\
\text { dapat bersaing } \\
\text { dengan produk } \\
\text { lainnya. }\end{array}$ \\
\hline
\end{tabular}

\subsection{Matriks IE}

Erly's kue berada pada posisi sel II, strategi yang dapat digunakan pada kondisi tersebut antara lain yaitu strategi utama (backward, forward, horizontal integration) dan strategi intensif (Market penetration Market development Product development) dimana kedua strategi tersebut merupakan strategi yang berfokus pada pembangunan dan pengembangan

\subsection{Matriks QSPM}

Matriks QSPM dapat dikatakan sebagai tahap pengambilan keputusan yang paling menguntungkan perusahaan, matriks QSPM merupakan alat untuk membantu perancang strategi dalam melakukan evaluasi strategi alternatif secara objektif. Matriks QSPM menggunakan input dari hasil analisis matriks IFE dan EFE serta pencocokan dengan analisis SWOT dan matriks IE yang telah dilakukan sebelumnya

Tabel QSPM yang telah diolah di atas diketahui nilai dengan menggunakan input analisis matriks EFE dan IFE serta pencocokan dari analisis SWOT dan IE, nilai didapatkan sebagai berikut:

1) Forward Integration memiliki nilai sebesar 4,23

2) Backward Integration memiliki nilai sebesar 4,77

3) Horizontal Integration memiliki nilai sebesar 5,30

4) Market penetration memiliki nilai sebesar 5,80

5) Market development memiliki nilai sebesar 5,76

6) Product development memiliki nilai sebesar 5,89

Dari hasil penghitungan tabel QSPM diketahui strategi pengembangan produk mendapat nilai yang paling besar yaitu 5,89 dibandingkan dengan lima strategi lainnya, sehingga perusahaan sebaiknya menerapkan strategi pengembangan produk. Perusahaan juga dapat menggabungkan strategi pengembangan produk dengan strategi integrasi horizontal, penetrasi pasar dan strategi pengembangan pasar karena nilai yang didapatkan dari hasil penghitungan tabel QSPM memiliki nilai yang tidak jauh besarnya

\section{7) Kesimpulan}

Kesimpulan yang dapat diambil berdasarkan hasil dari analisis dan penghitungan melalui berbagai matriks yang telah di lakukan pada bab-bab sebelumnya sebagai berikut:

\section{1) Visi dan Misi \\ Visi yang dimiliki perusahaan sudah} mengungkapkan tujuan yang jelas dari perusahaan untuk memberikan arah perusahaan berjalan, 
menentukan keputusan dan menggambarkan tanggung jawab sosial perusahaan.

Dalam misi yang dimiliki perusahaan, perusahaan sudah mengutamakan kepuasan dari konsumen, menjelaskan speciality dari produk, menjelaskan posisi perusahaan pada pasar, dan strategi perusahaan dalam mendapatkan keuntungan yang lebih besar. Misi perusahaan sebagian besar sudah mencakup faktor-faktor standar misi sesuai dengan yang dikemukakan oleh Fred R. David (2017).

\section{2) Analisis Internal}

Berdasarkan hasil identifikasi dari datadata yang didapatkan atas faktor-faktor internal Erly's Kue ditemukan beberapa kekuatan dan kelemahan. Melalui analisis dan hasil perhitungan menggunakan metode Internal Factor Evaluation (IFE) didapatkan total skor sebesar 3,19, dengan angka tersebut menyatakan bahwa kondisi internal perusahaan berada pada posisi yang kuat dan perusahaan mampu memaksimalkan kekuatan yang dimiliki perusahaan

Kekuatan yang dimiliki perusahaan didapatkan dari kekuatan produk dengan memperhatikan cita rasa dan kualitas yang tinggi, keberagaman produk yang ditawarkan, dan kapasitas produksi produk yang tinggi yang tinggi, dan quality control yang baik.

\section{3) Analisis Eksternal}

Berdasarkan hasil identifikasi dari datadata yang didapatkan atas lingkungan eksternal Erly's Kue ditemukan beberapa peluang dan ancaman. Melalui analisis dan hasil perhitungan menggunakan metode Eksternal Factor Evaluation (EFE) didapatkan total skor sebesar 3,34, dengan angka tersebut menyatakan bahwa perusahaan berada pada posisi yang bagus dalam menangkap dan merespons peluang dan ancaman yang sedang dihadapi perusahaan.

4) Strategi yang sesuai

Strategi mengembangkan produk(Product Development) dengan melakukan inovasi, variasi, dan peningkatan kuantitas produksi dapat dijadikan strategi alternatif yang dapat diimplementasikan dari product development yang didapat dari skor senilai 5,89 dari hasil penghitungan matriks QSPM. Strategi ini dapat dianggap sebagai strategi yang paling efektif untuk diterapkan untuk meningkatkan keunggulan kompetitif dalam menghadapi ancaman dan kelemahan sekaligus memperkuat daya saing perusahaan atas pesaing.

Strategi alternatif lainnya yang cocok untuk diimplementasikan oleh perusahaan berdasarkan nilai penghitungan matriks QSPM adalah strategi Market Penetration, market development, dan Horizontal Integration.

8) Saran

1) Melakukan inovasi produk dengan mengembangkan produk yang sudah ada dengan mempertahankan dan tetap meningkatkan kualitas produk.

2) Melakukan peningkatan sarana dan prasarana pada proses produksi untuk meningkatkan jumlah maksimum kapasitas produksi

3) Memanfaatkan perkembangan teknologi digital yang berkembang sangat cepat untuk memanfaatkan peluang bisnis yang ada.

4) Meningkatkan kualitas pelayanan dengan melakukan pelatihan dan pengawasan lapangan hingga budaya di lingkungan kerja terbentuk.

5) Melakukan kerja sama antara perusahaan dan pemasok untuk menekan biaya produksi dan 
mengurangi risiko perubahan harga bahan baku.

6) Memperluas wilayah operasional untuk meningkatkan penjualan dan menarik lebih banyak pemesanan dengan kuantitas besar.

7) Peningkatan promosi dengan memberikan promo agar nama perusahaan lebih dikenal oleh masyarakat dan memanfaatkan meningkatnya konsumsi masyarakat.

8) Memperketat kontrol jumlah produk yang produksi untuk mengurangi produk yang tidak laku terjual dan kedaluwarsa untuk mengurangi dan menekan biaya produksi yang tinggi.

9) Hasil QSPM menunjukkan strategi pengembangan produk merupakan strategi terbaik untuk diterapkan oleh perusahaan dengan jumlah nilai daya Tarik sebesar 5,89. Strategi penetrasi pasar dengan nilai 5,80 dan strategi pengembangan pasar dengan nilai 5,76 dapat dijadikan alternatif strategi lainnya dikarenakan total nilai daya tarik ketiganya sangat berdekatan.

10) Daftar Pustaka

David, F. R. (2011). Strategic Management: Concepts and Cases (Thirteenth Edition). In Prentice Hall.

David, F. R. (2017). Strategic Management: A Competitve Advantage Approach. In Pearson Education Limited .

Deputi Bidang Pengembangan Destinasi dan Industri Pariwisata Kementerian Pariwisata Republik Indonesia. (2016). Penggabungan petunjuk teknis dan ralat petunjuk teknis tata cara pendaftaran usaha pariwisata.

Fayol, H. (2013). Principios de Henry Fayol. Los 14 Principios de Henry Fayol.

Glos, Raymond E.; Steade, Richard D.; Lowry, J. R. (1984). Business : its nature and environment.
Hadiwijoyo, S. S. (1996). Pengertian Pariwisata. Jurnal Saintek Perikanan.

Hermiyati, I. H., Syabani, M. W. S., \& Silvianti, F. S. (2017). Vegetable Tanning Process Of Starry Trigger Fish (Abalistes Stellaris) And Its Plotting To Leather Products. The 7th International Seminar on Tropical Animal Production.

Menteri Hukum dan HAM Republik Indonesia (2009). Undang-Undang Republik Indonesia Nomor 10.Tahun 2009 Tentang Kepariwisataan (1242).

Mokhtar, G., \& Siena, J. S. (1992). Gamal Mokhtar: a life devoted to Egypt's cultural heritage. Conservation: The GCI Newsletter.

Nawawi, H. (2005). Manajemen Strategik Organisasi Non-Profit Bidang Pemerintahan. In Gajah Mada University Press.

Porter, M. E. (1998). Competitive Strategy: Techniques for Analyzing Industries and Competitors.

Prahalad, C. K., \& Hamel, G. (2009). The core competence of the corporation. In Knowledge and Strategy. https://doi.org/10.1016/b978-07506-7223-8.50003-4

Sherrell, D. L., Hair, J. F., \& Griffin, M. (1989). Marketing academicians' perceptions of ethical research and publishing behavior. Journal of the Academy of Marketing Science. https://doi.org/10.1007/BF02726642

Sugiyono. (2012). Statistik Untuk Pendidikan. In Statistika Untuk Penelitian.

Sugiyono. (2014). Metode Penelitian Pendidikan pendekatan Kuantitatif, Kualitatif dan R\&D. In METODE PENELITIAN ILMIAH. 